Prepared in cooperation with the City of Tallahassee

\title{
Depth-Dependent Groundwater Quality Sampling at City of Tallahassee Test Well 32, Leon County, Florida, 2013
}

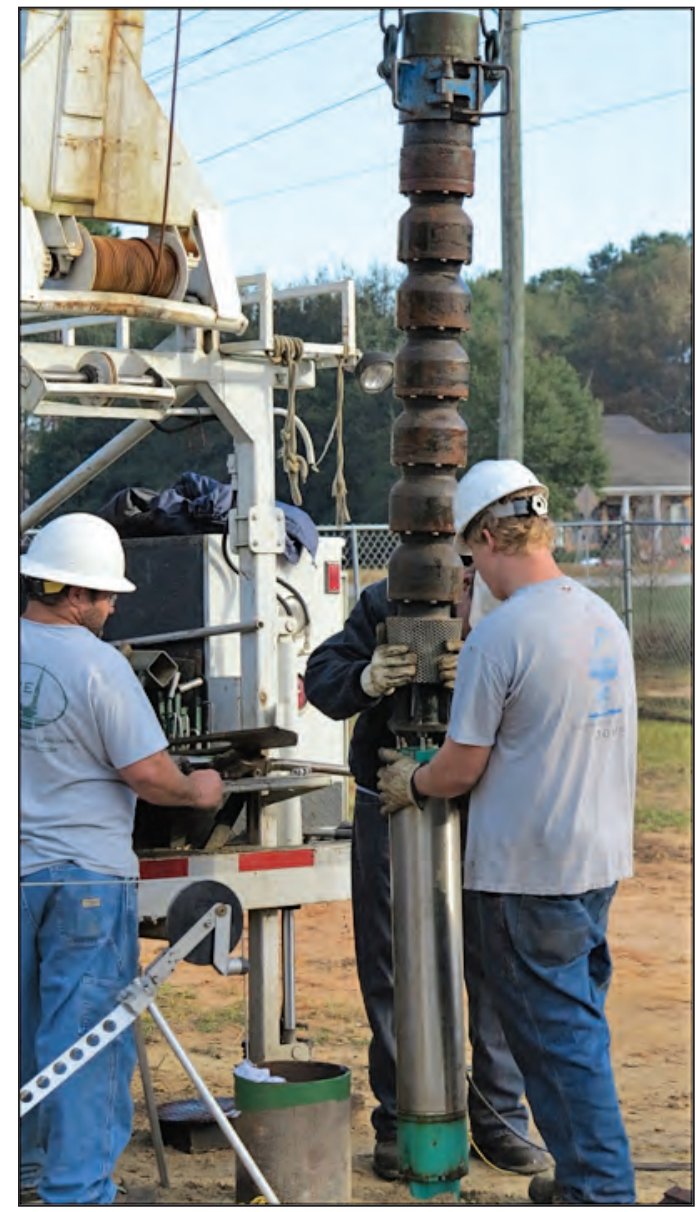

Open-File Report 2014-1255 
Cover. Well drillers installing submersible pump in well 32. Photograph by W. Scott McBride, USGS. 


\section{Depth-Dependent Groundwater Quality Sampling at City of Tallahassee Test Well 32, Leon County, Florida, 2013}

By W. Scott McBride and Michael A. Wacker

Prepared in cooperation with the City of Tallahassee

Open-File Report 2014-1255 


\title{
U.S. Department of the Interior SALLY JEWELL, Secretary
}

\section{U.S. Geological Survey Suzette M. Kimball, Acting Director}

\author{
U.S. Geological Survey, Reston, Virginia: 2015
}

For more information on the USGS - the Federal source for science about the Earth, its natural and living resources, natural hazards, and the environment—visit http://www.usgs.gov or call 1-888-ASK-USGS.

For an overview of USGS information products, including maps, imagery, and publications, visit http://Www.usgs.gov/pubprod

To order this and other USGS information products, visit http://store.usgs.gov

Any use of trade, firm, or product names is for descriptive purposes only and does not imply endorsement by the U.S. Government.

Although this information product, for the most part, is in the public domain, it also may contain copyrighted materials as noted in the text. Permission to reproduce copyrighted items must be secured from the copyright owner.

Suggested citation:

McBride, W.S., and Wacker, M.A., 2015, Depth-dependent groundwater quality sampling at City of Tallahassee test well 32, Leon County, Florida, 2013: U.S. Geological Survey Open-File Report 2014-1255, 13 p. and 2 appendixes, http://dx.doi.org/10.3133/ofr20141255.

ISSN 2331-1258 (Online) 


\section{Contents}

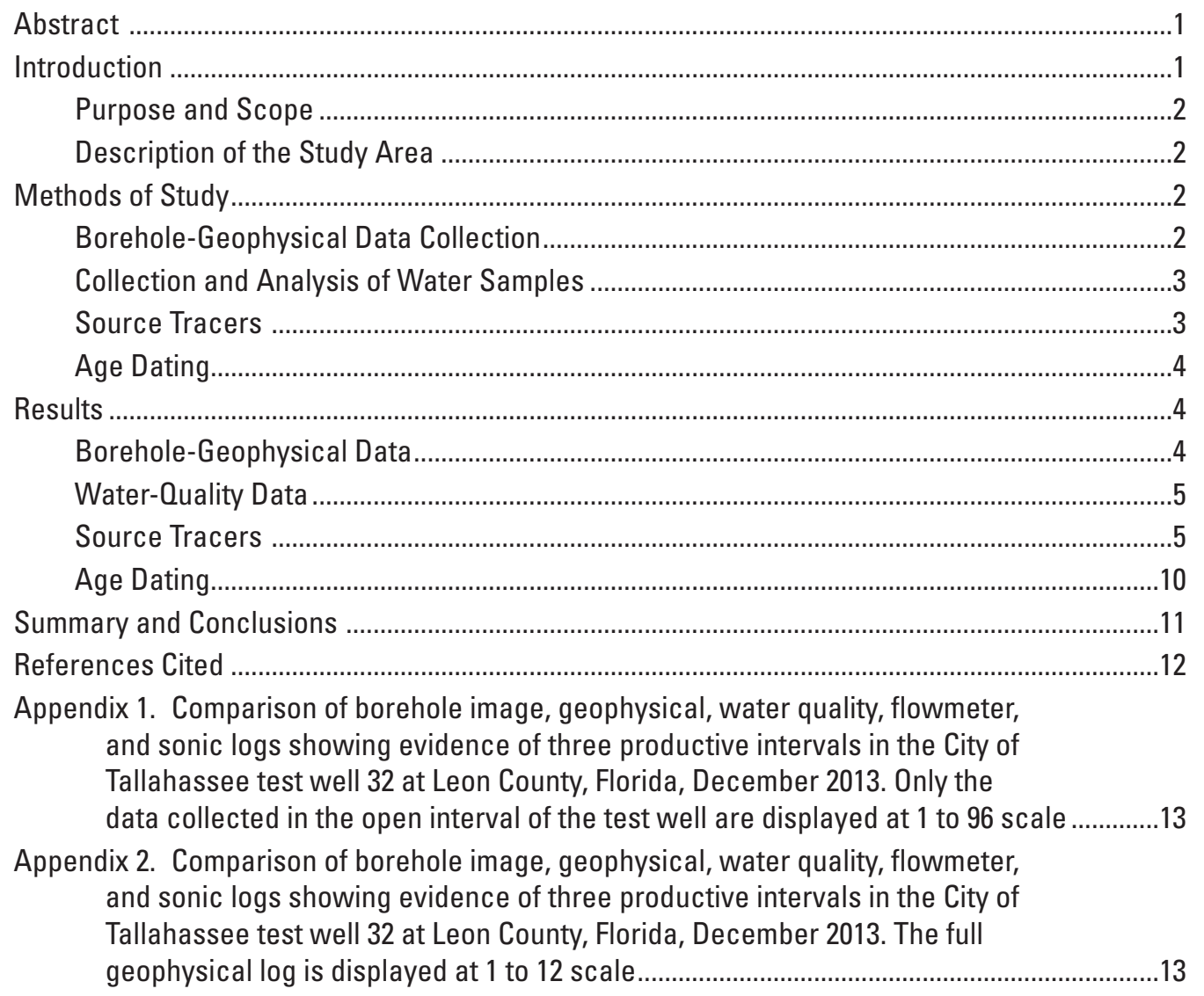




\section{Figures}

1. Map showing City of Tallahassee test well 32 in Leon County, Florida

2. Stiff diagrams comparing the major ion concentrations of four water samples collected at the City of Tallahassee test well 32, December 2013.

3. Graph showing content of delta deuterium and delta oxygen-18 in water samples collected from the City of Tallahassee test well 32 relative to the global meteoric water line in December 2013

4. Graph showing relation between strontium isotope ratios and the inverse of the strontium concentration in water samples collected at the City of Tallahassee test well 32, December 2013

\section{Tables}

1. Major ions, nutrients, and trace elements in groundwater samples collected at the City of Tallahassee test well 32, December 2013.

2. Volatile organic compounds in groundwater samples collected from City of Tallahasse test well 32, December 2013.

3. Field measurements, tracer, and age data collected from City of Tallahassee test well 32, December 2013 


\section{Conversion Factors and Datums}

\begin{tabular}{lll}
\hline \multicolumn{1}{c}{ Multiply } & \multicolumn{1}{c}{ By } & \multicolumn{1}{c}{ To obtain } \\
\hline inch (in.) & Length & \\
foot (ft) & 2.54 & centimeter $(\mathrm{cm})$ \\
mile (mi) & 0.3048 & meter $(\mathrm{m})$ \\
\hline & 1.609 & kilometer $(\mathrm{km})$ \\
\hline square mile $\left(\mathrm{mi}^{2}\right)$ & Area & \\
\hline & 2.590 & square kilometer $\left(\mathrm{km}^{2}\right)$ \\
\hline gallon per minute $(\mathrm{gal} / \mathrm{min})$ & Flow rate & \\
inch per year (in/yr) & 0.06309 & liter per second $(\mathrm{L} / \mathrm{s})$ \\
\hline
\end{tabular}

Temperature in degrees Fahrenheit $\left({ }^{\circ} \mathrm{F}\right)$ may be converted to degrees Celsius $\left({ }^{\circ} \mathrm{C}\right)$ as follows:

$$
{ }^{\circ} \mathrm{C}=\left({ }^{\circ} \mathrm{F}-32\right) / 1.8
$$

Vertical coordinate information is referenced to the National Geodetic Vertical Datum of 1929 (NGVD 29).

Horizontal coordinate information is referenced to the North American Datum of 1983 (NAD 83).

Altitude, as used in this report, refers to distance above the vertical datum.

Specific conductance is given in microsiemens per centimeter at 25 degrees Celsius $(\mu \mathrm{S} / \mathrm{cm}$ at $\left.25^{\circ} \mathrm{C}\right)$.

Concentrations of chemical constituents in water are given either in milligrams per liter (mg/L) or micrograms per liter $(\mu \mathrm{g} / \mathrm{L})$.

\section{Abbreviations}

$\begin{array}{llll}\mathrm{ABI} & \text { acoustic borehole imager } & \mathrm{OBI} & \text { optical borehole imager } \\ \text { bls } & \text { below land surface } & \text { per mil } & \text { parts per thousand } \\ \mathrm{cps} & \text { counts per second } & \mathrm{SF}_{6} & \text { sulfur hexafluoride } \\ \mathrm{CW} 32 & \text { test well } 32 & { }^{86} \mathrm{Sr} & \text { strontium-86 } \\ \delta^{18} \mathrm{O} & \text { delta oxygen-18 } & { }^{87} \mathrm{Sr} & \text { strontium-87 } \\ \delta^{2} \mathrm{H} & \text { delta hydrogen-2 } & \mathrm{SFM} & \text { spinner flowmeter } \\ \mathrm{EM} & \text { electromagnetic } & \mathrm{TU} & \text { tritium units } \\ { }^{2} \mathrm{H} & \text { deuterium } & \text { USGS } & \text { U.S. Geological Survey } \\ { }^{3} \mathrm{H} & \text { tritium } & \text { WOT } & \text { water-quality tool } \\ \mathrm{KHz} & \text { kilohertz } & & \end{array}$




\section{Acknowledgments}

The authors would like to thank Dr. Brian Katz, retired U.S. Geological Survey and currently Florida Department of Environmental Protection, and David Roberts, City of Tallahassee, who originally conceived of this investigation. Their advice and consultation during the planning and execution of the study are much appreciated.

The authors also thank Dr. Kim Haag, Reports Specialist for the USGS Caribbean-Florida Water Science Center, for her substantial contributions in preparing this report for publication. Dr. Haag reviewed, revised, and formatted the report with great efficiency and her efforts are appreciated. 


\title{
Depth-Dependent Groundwater Quality Sampling at City of Tallahassee Test Well 32, Leon County, Florida, 2013
}

\author{
By W. Scott McBride and Michael A. Wacker
}

\begin{abstract}
Public-supply wells sometimes produce water of less than desirable quality because contaminants can migrate to the open interval of wells through preferential pathways. If these pathways can be identified, zones that produce poor quality water can be excluded during the well-construction process. The U.S. Geological Survey has developed geophysical testing methods that can be used to delineate zones of high permeability in test wells. Once the highly permeable zones are identified, water-quality data can be collected from each zone to identify whether any of the zones produce water of poor quality. The zones producing poor quality water can then be cased off in the final well design so that they do not contribute flow to the production well, reducing subsequent water-treatment costs.

A test well was drilled by the City of Tallahassee to assess the suitability of the site for the installation of a new well for public water supply. The test well is in Leon County in north-central Florida. The U.S. Geological Survey delineated high-permeability zones in the Upper Floridan aquifer, using borehole-geophysical data collected from the open interval of the test well. A composite water sample was collected from the open interval during high-flow conditions, and three discrete water samples were collected from specified depth intervals within the test well during low-flow conditions. Water-quality, source tracer, and age-dating results indicate that the open interval of the test well produces water of consistently high quality throughout its length. The cavernous nature of the open interval makes it likely that the highly permeable zones are interconnected in the aquifer by secondary porosity features.
\end{abstract}

\section{Introduction}

Public-supply wells are vulnerable to water-quality issues due to the movement of contaminants through short-circuit pathways that can be induced by pumping and other processes (Landon and others, 2009). Large costs can be associated with the installation and maintenance of a public-supply well used to provide a clean, safe, and reliable source of drinking water. Treatment costs can be minimized if the spatial distribution of zones of substantial flow and high-quality water can be delineated in test wells prior to the construction of a publicsupply well.

The City of Tallahassee operates 28 water-supply wells throughout the city and surrounding areas that draw water from the Upper Floridan aquifer (Davis and Katz, 2007). In general, high-quality groundwater is being withdrawn; however, problems have been identified in a few of the wells, with slightly elevated concentrations of iron, manganese, arsenic, nitrate, and tetrachloroethylene. To meet a growing demand for additional public water supply, the City of Tallahassee plans to complete a new public-supply well north of the city. Test well 32 (CW32) was drilled to confirm the suitability of the water in the open interval for public water supply (fig. 1).

The U.S. Geological Survey (USGS) has developed depth-dependent sampling techniques that can be used to collect water-quality samples and flow-rate data from discrete depth intervals within public-supply wells and boreholes during pumping and non-pumping conditions.

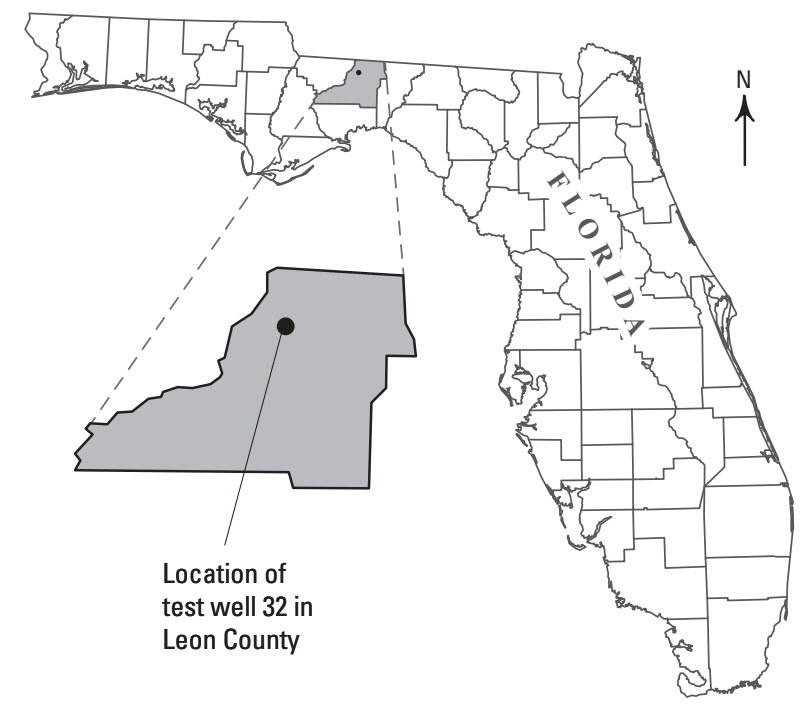

Figure 1. City of Tallahassee test well 32 in Leon County, Florida. 
Depth-dependent flow and water-chemistry profiles in pumped wells are useful for understanding sources and pathways for contaminants to supply wells (Collar and Mock, 1997; Gossell and others, 1999; Izbicki and others, 1999, 2005, 2008; Danskin and Church, 2005).

\section{Purpose and Scope}

The purpose of this report is to present the findings of a study conducted by the USGS, in cooperation with the City of Tallahassee, to (1) delineate high-permeability zones in the Upper Floridan aquifer at test well CW32 that have substantial rates of groundwater flow and (2) to characterize changes in water quality with depth in the CW32 borehole. Delineation of the high-permeability zones in the Upper Floridan aquifer was determined using a suite of geophysical logging tools. Composite water samples were collected from the open interval, and discrete depth-dependent samples were collected from each of the three productive zones in CW32. Data were collected during December 2013. Water samples were analyzed for a variety of water-quality constituents including major ions, nutrients, dissolved organic carbon, trace elements, volatile organic compounds; natural tracers including isotopes of oxygen, hydrogen, and strontium; and age-dating indicators including tritium and sulfur hexafluoride.

\section{Description of the Study Area}

The study area is in Leon County in north-central Florida (fig. 1). The topography of the study area is characterized by rolling hills and land-surface altitudes that range from 0 to about 200 feet above the National Geodetic Vertical Datum of 1929. The climate is humid, subtropical with relatively large amounts of rainfall. The average annual temperature in Tallahassee is 67 degrees Fahrenheit, and the annual average precipitation is about 66 inches per year. The city water-supply wells are widely distributed, and all 28 existing wells are interconnected through distribution lines. City of Tallahassee test well 32 is located approximately 9 miles north of downtown Tallahassee, about 2.5 miles west of Thomasville Road in the Summerbrooke Subdivision.

\section{Methods of Study}

Borehole-geophysical data were collected in the open interval of CW32 to delineate zones of high permeability and flow. Water chemistry data were collected and used to determine the quality of water produced by the high-permeability zones in CW32. Naturally occurring chemical tracers were used to determine whether the high-flow zones in CW32 yield water from similar sources. Transient age-dating tracers were used to determine if water from each of the highly permeable zones in CW32 is of similar age.

\section{Borehole-Geophysical Data Collection}

The total depth of the CW32 borehole drilled by the City of Tallahassee is 440 feet (ft) below land surface (bls), with a casing depth of $300 \mathrm{ft}$ and a borehole diameter of 10 inches (in.). Prior to the collection of borehole-geophysical data, the borehole was bridged or collapsed below $413 \mathrm{ft}$ bls, and therefore, borehole data were collected between the base of the casing and $413 \mathrm{ft}$ (natural gamma ray log data were collected from the land surface to $413 \mathrm{ft}$ bls). Borehole-geophysical data from CW32 were collected in two stages on December 2-3, 2013. On December 2, continuous digital borehole images, fluid, caliper, natural gamma, electromagnetic-induction, and acoustic velocity data were collected. WellCAD version 4.4 was used to plot the borehole data and to display the data at different scales (1 to 96 and 1 to 12 scales) to better depict the range of data in the discrete well intervals. This data display was used to plan the subsequent collection of flowmeter data on the following day.

Continuous digital borehole images were obtained using high-resolution optical borehole image (OBI) and an acoustic borehole image (ABI) devices. The ABI data supplement data from the OBI by displaying physical features that may be difficult to distinguish optically (Williams and Johnson, 2004). In addition, the amplitude of the acoustic signal reflects the density and cementation of the rock in the borehole wall (Prensky, 1999; Williams and Johnson, 2004).

Fluid data were collected in the open section of the borehole under ambient flow conditions, using two instruments: (1) a water-quality tool (WQT) that measures fluid temperature, specific conductance, $\mathrm{pH}$, percent oxygen, and oxidation-reduction potential (redox) of the borehole fluid and (2) a fluid probe on the end of a caliper tool that measures borehole-fluid temperature and resistivity.

Other borehole-geophysical data were collected using a three-arm caliper probe, natural gamma tool, electromagnetic (EM) induction tool, and acoustic velocity tool. The threearm caliper probe was used to measure the diameter of the borehole with depth and to locate zones of potential secondary porosity (Keys, 1990). Natural gamma data typically are used to correlate changes in lithology and stratigraphy between boreholes (Keys, 1990). An electromagnetic induction tool was used to provide bulk electrical conductivity data for the aquifer rock matrix and formation water. These data are influenced by formation porosity, groundwater specific conductance, and temperature (Wacker and others, 2014). Formation resistivity is the reciprocal of conductivity, so EM induction data are comparable to resistivity data (Keys, 1990). Acoustic velocity logs were recorded using full waveform sonic data collected over the open-hole section in two logging runs with one acoustic signal transmitted at 15 kilohertz (KHz; data used for porosity calculations) and a second signal transmitted at $1 \mathrm{KHz}$ (data used for relative permeability).

On December 3, 2013, a spinner flowmeter (SFM) was used, under both ambient and pumping conditions, to measure the relative change in flow as the tool was moved up and down 
the borehole. The SFM measures flow using a propeller that spins faster or slower depending on the rate of vertical flow within the borehole. Depths where changes in spin velocity occur, measured in counts per second (cps), indicate locations where inflow and outflow of groundwater to the borehole occurs. Heat-pulse and electromagnetic flowmeters, which measure the actual velocity of flow in the well bore, were not used because these meters require the borehole to be of a uniform diameter. Heat-pulse and electromagnetic flowmeters require that water be routed through a central measuring orifice by way of a rubber diverter. When the borehole wall is not uniform, flow can escape around the diverter, biasing the measurement. The SFM can be used in boreholes that are cavernous, like CW32, because it does not require that flow be confined in order for a measurement to be obtained.

The SFM was first logged up and down the open borehole under ambient flow conditions. After the ambient logging was completed, an electrical submersible pump was installed in the well at $230 \mathrm{ft}$ bls. This was done while the SFM was still in the borehole, because there was insufficient space in the well casing for the pump and SFM to pass one another. The SFM was then moved up and down the borehole as the pump was run at different speeds to measure the vertical flow in the borehole under varying pumping conditions. Fluid data were also collected with the WQT after pumping was completed (and the pump removed) to determine if the borehole fluid had returned to ambient pre-pumping conditions. The WQT was not used during pumping because it would have required the removal of the pump from the test well.

\section{Collection and Analysis of Water Samples}

Composite and discrete depth-dependent water samples were collected at CW32 by the City of Tallahassee and the USGS. To collect the composite sample, which represents the quality of water produced by the entire open interval of the test well under pumping conditions, a 6-in.-diameter submersible pump was set at $301 \mathrm{ft}$ near the bottom of the well casing. A sampling port was installed on the side of the pump discharge pipe. Sample water passed through the port into Teflon tubing attached to a sampling chamber that protected the samples from atmospheric contamination during collection. The well was purged three volumes and, during the third volume, water chemistry was monitored for stability using a calibrated multiparameter water-quality instrument. Field readings consisted of specific conductance, $\mathrm{pH}$, temperature, and dissolved oxygen measurements. On December 2, after USGS stabilization criteria were met, both the USGS and the City of Tallahassee collected a composite water-quality sample from the open interval of the test well (300-440 ft bls) while pumping at approximately 550 gallons per minute (gal $/ \mathrm{min})$.

Discrete depth-dependent water samples were collected within the open interval of the test well from the highly permeable flow zones that were identified using geophysical logs. On December 3, before sampling began, the drill crew installed a 4-in.-diameter submersible pump in CW32 capable of pumping about $60 \mathrm{gal} / \mathrm{min}$. The $60-\mathrm{gal} / \mathrm{min}$ flow rate was ideal for discrete sampling because it allowed CW32 to be purged in less than 1 hour between samples, but the flow rate was low enough that it was not likely to induce intra-borehole flow over the length of the open interval and cause mixing of waters from each highly permeable zone. Ideally, packers would have been used to isolate each zone during sample collection, but the cavernous borehole precluded their use. The huge volume of water contained in the cavernous borehole makes it highly unlikely that mixing occurred at a flow rate of $60 \mathrm{gal} / \mathrm{min}$. The same sample collection procedures described above for the composite sample were followed for each of the discrete depth-dependent samples. The test well was purged at least three volumes, and field parameter stability was re-established, each time the pump was moved to a new highly permeable zone. Purge volume calculations were based on borehole volume alone, since it was impossible to estimate the volume of water contained in the cavernous portion of the open interval.

Water samples collected by the City of Tallahassee were analyzed for major ions, nutrients, dissolved organic carbon, trace elements, and volatile organic compounds by the City of Tallahassee Water-Quality Laboratory. The USGS collected water samples following methods described in the USGS National Field Manual for the Collection of Water-Quality Data (U.S. Geological Survey, variously dated). Water samples collected by the USGS were analyzed for tracers (including isotopes of oxygen, hydrogen, and strontium) and age-dating indicators (including tritium and sulfur hexafluoride). The samples collected by the USGS were analyzed at USGS research laboratories, including the Stable Isotope and Groundwater Dating Laboratories in Reston, Virginia, and the Tritium and Radiogenic Isotope Laboratories in Menlo Park, California.

\section{Source Tracers}

The stable isotopes of hydrogen $\left({ }^{2} \mathrm{H} / \mathrm{H}\right)$ and oxygen $\left({ }^{18} \mathrm{O} /{ }^{16} \mathrm{O}\right)$ are naturally occurring tracers that were used to determine whether the high-flow zones in CW32 produce water from similar sources. Rainfall around the world contains a consistent ratio of ${ }^{18} \mathrm{O} /{ }^{16} \mathrm{O}$ and ${ }^{2} \mathrm{H} / \mathrm{H}$ known as the "global meteoric water line" (GMWL; Craig, 1961). Isotope data are presented using delta $(\delta)$ notation, expressed as the ratio of the heavy to the light isotope, normalized to a standard:

$$
\delta_{\text {sample }}=1,000\left[\left(\mathrm{R}_{\text {sample }} / \mathrm{R}_{\text {standard }}\right)-1\right]
$$

where $\mathrm{R}_{\text {sample }}$ and $\mathrm{R}_{\text {standard }}$ are the ratio of the heavy to the light isotope in the sample and in the standard, respectively. Delta hydrogen-2 $\left(\delta^{2} \mathrm{H}\right.$, deuterium $)$ and delta oxygen- $18\left(\delta^{18} \mathrm{O}\right)$ are reported relative to Vienna Standard Mean Ocean Water (Coplen and others, 1991). Results are reported in units of per mil (parts per thousand). 
The isotopic variability along the GMWL depends on several factors, including the origin of storms, rainfall intensity and amount, and atmospheric temperature (Dansgaard, 1964). After rainfall, water at land surface undergoes varying degrees of isotopic fractionation because of evaporation and other kinetic processes. Fractionation imparts a unique isotopic signature on water molecules that is maintained after recharge and allows groundwater to be traced to its source.

Strontium isotopes $\left({ }^{87} \mathrm{Sr} /{ }^{86} \mathrm{Sr}\right)$ are another natural tracer that was used to determine the geologic formation from which each highly permeable zone in CW32 yields water. Each formation has a unique range of isotopic ratios that correspond to the ${ }^{87} \mathrm{Sr} /{ }^{86} \mathrm{Sr}$ composition of the shallow seas in which the deposition of aquifer materials occurred. Groundwater reflects the same isotopic ratio as its host rock, so the source formation can be determined by comparing the ${ }^{87} \mathrm{Sr} r{ }^{86} \mathrm{Sr}$ ratio of a water sample with the known ratios of each aquifer formation (Katz and Bullen, 1996).

\section{Age Dating}

Sulfur hexafluoride $\left(\mathrm{SF}_{6}\right)$ and tritium $\left({ }^{3} \mathrm{H}\right)$ data were used to determine the similarity in age of the water from each of the highly permeable zones in CW32, thereby determining the connectedness of the flow system. Groundwater "age" is defined as the length of time a parcel of water has been isolated from the atmosphere, typically when water recharges to the groundwater system. Sulfur hexafluoride is a known greenhouse gas and is primarily used as an electrical insulator in high-voltage switches (Busenberg and Plummer, 2000). The atmospheric concentration of $\mathrm{SF}_{6}$ has steadily increased since the 1960s, which makes it useful for dating groundwater that has recharged since that time. Atmospheric moisture carries $\mathrm{SF}_{6}$ from the atmosphere to the surface, where it enters the groundwater system. A sample of water withdrawn from the groundwater flow system can then be dated by comparing the concentration of $\mathrm{SF}_{6}$ in the sample with known atmospheric concentrations over time (Busenberg and Plummer, 2000).

Tritium $\left({ }^{3} \mathrm{H}\right)$ is a radioactive isotope of hydrogen with a half-life of 12.43 years. Tritium occurs naturally in the Earth's atmosphere, but levels rose sharply after hydrogen bomb testing began in the 1950s. The concentration of ${ }^{3} \mathrm{H}$ has steadily declined since 1963, when above-ground testing was banned, and now approaches natural background levels. Rainfall typically contains the same concentration of ${ }^{3} \mathrm{H}$ as the atmosphere in which the rainfall originated, and this concentration is maintained as it recharges the groundwater. Radioactive decay, however, prevents ${ }^{3} \mathrm{H}$ from being used, in the absence of other properties needed for corrections, to date groundwater in the way $\mathrm{SF}_{6}$ is used. Tritium by itself is useful for qualifying whether groundwater contains a mixture of young and old "pre-bomb" water. Water containing no measureable ${ }^{3} \mathrm{H}$ has been isolated from the atmosphere since at least the mid-1950s (Ingraham, 1998).

\section{Results}

Three zones of high permeability were identified in the CW32 borehole. Water-quality, tracer, and age-dating results indicate that the open interval of CW32 produces water of consistent and high quality throughout its length. The cavernous nature of the open interval makes it likely that the highly permeable zones are interconnected in the aquifer by secondary porosity features.

\section{Borehole-Geophysical Data}

Borehole-geophysical data collection was completed in CW32 during December 2-3, 2013, to delineate zones of high permeability and support collection of depth-dependent groundwater samples. OBI and ABI data indicated that below $343 \mathrm{ft}$ bls the lithology appeared to be limestone with several large interconnected cavities. On the basis of caliper data, the cavities exceed 26 in. in diameter, the maximum diameter to which the caliper arms can extend. One such cavity is $15 \mathrm{ft}$ long and is located 350 to $365 \mathrm{ft}$ bls (appendixes 1 and 2). On the basis of borehole image and caliper data, the borehole wall above $343 \mathrm{ft}$ bls also appears to be limestone containing strata of varying porosity. In the interval above $343 \mathrm{ft}$ bls, the caliper remained fully engaged with the borehole wall and the diameter was consistently less than 14 in.

Borehole fluid, natural gamma, and electromagneticinduction data indicated results similar to the image logs, whereby there was a noticeable difference in the data above and below $343 \mathrm{ft}$ (appendixes 1 and 2). Minor changes in fluid properties, a decrease in fluid temperature, and an increase in specific conductance were observed at about 305 and $390 \mathrm{ft}$ bls. Natural gamma and EM induction data had higher values and a greater range that varied with borehole diameter, indicating that the lithology above and below $343 \mathrm{ft}$ bls may be similar and that the differences could be the result of changes in borehole diameter. In the cavernous section below $343 \mathrm{ft}$, the data from the full waveform sonic tool were unreliable due to borehole diameter, except where the borehole wall was close to the drilled diameter.

Under ambient flow conditions prior to pumping from the well, the SFM was logged both up and down the well bore, and no observable flow was detected. The lack of measurable flow is substantiated by the change in fluid properties with depth, especially the change in fluid conductance. The change in conductance with depth is an indication that no flow or mixing occurs over the length of the open-hole section under ambient conditions.

Under pumping conditions, most of the inflow from CW32 (as indicated by a change in counts per second of the SFM) originated from between 339 and $350 \mathrm{ft}$ bls. This zone accounted for about 38 percent of the total well discharge. This zone of inflow may extend deeper to $365 \mathrm{ft}$ bls, but flow within the cavernous zone cannot be measured with accuracy 
(appendixes 1 and 2). Smaller zones of inflow were noted by the SFM data in the intervals $307-311 \mathrm{ft}$ and $387-390 \mathrm{ft}$ bls, with each accounting for about 25 percent of the total discharge. The pumped flow data were collected after an electrical submersible pump was installed in CW32. No testing was performed until after the rate of discharge stabilized. An inline flowmeter was installed on the pump discharge line, but it did not appear to operate properly, perhaps because of cavitation within the line. The flow rate was estimated to be about $550 \mathrm{gal} / \mathrm{min}$ using a bucket and stopwatch. Attempts were made to run the pump at varying speeds, but there was no apparent change in the rate of discharge. The lack of apparent change was supported by different logging runs of the SFM, which indicated no difference in flow velocity as the pump speed was varied.

Approximately 3 hours after the pump was stopped and removed from CW32, the WQT was run a second time to determine how quickly fluid properties return to ambient pre-pumping conditions. Higher fluid conductance values were logged in the section above $343 \mathrm{ft}$ bls (316 microsiemens per centimeter $(\mu \mathrm{S} / \mathrm{cm})$ at 25 degrees Celsius versus $260 \mu \mathrm{S} / \mathrm{cm}$ under ambient conditions) than were recorded prior to the test (appendix 1). These data are an indication that the $550 \mathrm{gal} / \mathrm{min}$ pump rate was sufficient to induce flow over the entire open interval of the test well. Minor changes in other borehole fluid properties, including temperature, $\mathrm{pH}$, percent oxygen, and redox potential, were similar to the pre-pumping ambient conditions.

Following analyses of all the borehole-geophysical data, three highly permeable zones were delineated within the logged open interval of CW32 at $307-311 \mathrm{ft}, 339-350 \mathrm{ft}$, and 387-390 ft. Pump placement was limited by the $20-\mathrm{ft}$ length of each section of drop pipe attached to the pump and by the length of the pump housing itself, so it was not always possible to place the pump intake exactly adjacent to a permeable zone. Therefore, discrete depth-dependent water samples were collected at 301, 343, and $385 \mathrm{ft}$ bls.

\section{Water-Quality Data}

Water-quality data, including major ions, nutrients, trace elements, and volatile organic compounds, were consistent between samples with the exceptions of lead, copper, zinc, and toluene (tables 1, 2). Stiff diagrams, prepared using major ion data from each of the four samples, are nearly identical in shape (fig. 2). A Stiff diagram graphically displays the proportion of major ions in individual samples in a way that allows rapid visual comparison of the data on the basis of shape. The similarity of the major ion composition of the four samples indicates that the water has followed similar flow paths through the aquifer system.

Concentrations of lead, copper, zinc, and toluene tended to increase with depth, but were below established drinking water criteria (U.S. Environmental Protection Agency, 2014). It is unlikely that these constituents are present in the aquifer at the concentrations found in the samples. The samples likely were contaminated as the water passed through the drop pipe that supported the submersible pump. The pipe joints were coated with thread lubricant (pipe dope) at the connections, and all four of these substances are common ingredients in this type of lubricant. The galvanized finish on the pipes also may have contributed to sample contamination, especially with zinc, as it is the primary ingredient used in the galvanization process.

\section{Source Tracers}

Results for $\delta^{18} \mathrm{O}$ and $\delta^{2} \mathrm{H}$ tracer data indicate that all four water samples originated from a similar source that is slightly enriched in isotopic composition compared to meteoric waters. Values for $\delta^{18} \mathrm{O}$ ranged from -2.69 to -2.78 per mil, whereas $\delta^{2} \mathrm{H}$ values ranged from -12.9 to -15 per mil (fig. 3 ). Water produced by CW32 contains a fraction of water recharged from a standing surface-water source, on the basis of the slightly enriched isotopic signature found in all of the samples collected from the test well. The composite sample was the most enriched of all the samples, likely because this sample contained a relatively large fraction of water recharged from standing surface-water sources. The higher pump rate (550 gal/min) used during the collection of the composite sample likely drew water in from shallower sources. The surface water could originate through a short-circuit pathway such as a sinkhole. Several sinkhole lakes and ponds are upgradient from CW32, including Lake Iamonia in the Summerbrooke Subdivision, and could be a source of this surface water. Alternatively, surface water could be drawn into the aquifer as a consequence of aquifer pumping at a point distant from the test well. This finding is consistent with results inferred for a site near this location and reported by Katz and others (1997), who determined that several City of Tallahassee production wells pumped groundwater mixed with a small percentage of surface water even though the wells were greater than about $200 \mathrm{ft}$ deep.

Results for ${ }^{87} \mathrm{Sr} /{ }^{86} \mathrm{Sr}$ analyses indicate that water from all four samples followed a similar flow path through the Upper Floridan aquifer. Katz and Bullen (1996) analyzed rock cores collected from the Upper Floridan aquifer and determined that ${ }^{87} \mathrm{Sr} /{ }^{86} \mathrm{Sr}$ ratios for Eocene-aged Ocala Limestone vary from 0.7081 to 0.7085 per mil. Isotopic ratios in the four water samples collected at CW32 ranged from 0.70824 to 0.70829 per mil, indicating that the Ocala Formation within the Upper Floridan aquifer is clearly the primary source of water to the test well (fig. 4). This result is expected because the open interval in the test well likely spans all or most of the Ocala Formation according to published estimates of aquifer depth and thickness (Miller, 1986). 
Table 1. Major ions, nutrients, and trace elements in groundwater samples collected at the City of Tallahassee test well 32 , (U.S. Geological Survey site 303408084152300 COT 440 ft UFA Test Well at Tallahassee, FL), December 2013.

[ft, feet; EST, Eastern Standard Time; $\mathrm{CaCO}_{3}$, calcium carbonate; $\mu \mathrm{g} / \mathrm{L}$, micrograms per liter; <, less than; mg/L, milligrams per liter; $\mathrm{CU}$, color units; ND, no data; N, nitrogen; TON, threshold odor number; NOD, no odor detected; ${ }^{\circ} \mathrm{C}$, degrees Celsius; $\mathrm{Ca}$, calcium; NTU, nephelometric turbidity units]

\begin{tabular}{|c|c|c|c|c|}
\hline Sample description & $\begin{array}{l}\text { Composite sample } \\
\text { from } 300 \text { to } 440 \mathrm{ft}\end{array}$ & $\begin{array}{l}\text { Depth-dependent } \\
\text { sample at } 301 \mathrm{ft}\end{array}$ & $\begin{array}{l}\text { Depth-dependent } \\
\text { sample at } 343 \mathrm{ft}\end{array}$ & $\begin{array}{l}\text { Depth-dependent } \\
\text { sample at } 385 \mathrm{ft}\end{array}$ \\
\hline Date (EST) & $12 / 3 / 2013$ & $12 / 4 / 2014$ & $12 / 4 / 2013$ & $12 / 4 / 2013$ \\
\hline Time & 1600 & 1500 & 1400 & 1200 \\
\hline Alkalinity, $\mathrm{mg} / \mathrm{L} \mathrm{CaCO}_{3}$ & ND & 176 & 175 & 175 \\
\hline Antimony, total, $\mu \mathrm{g} / \mathrm{L}$ & $<2.49$ & $<2.49$ & $<2.49$ & $<2.49$ \\
\hline Arsenic, total, $\mu \mathrm{g} / \mathrm{L}$ & $<1.39$ & $<1.39$ & $<1.39$ & $<1.39$ \\
\hline Cadmium, total & $<0.09$ & $<0.09$ & $<0.09$ & $<0.09$ \\
\hline Chloride, mg/L & ND & 3.8 & 3.9 & 3.9 \\
\hline Color, CU & ND & $<1$ & $<1$ & $<1$ \\
\hline $\mathrm{pH}$ & ND & 7.7 & 7.7 & 7.7 \\
\hline Fluoride, $\mathrm{mg} / \mathrm{L}$ & ND & $<0.20$ & $<0.19$ & $<0.19$ \\
\hline Chlorine, free available, $\mathrm{mg} / \mathrm{L}$ & $<0.0$ & $<0.0$ & $<0.0$ & $<0.0$ \\
\hline Lead, total, $\mu \mathrm{g} / \mathrm{L}$ & $<1.32$ & $<1.32$ & 1.87 & 3.32 \\
\hline Mercury, total, $\mu \mathrm{g} / \mathrm{L}$ & $<0.42$ & $<0.42$ & $<0.42$ & $<0.42$ \\
\hline Aluminum, total, $\mu \mathrm{g} / \mathrm{L}$ & $<2.68$ & $<2.68$ & $<2.68$ & $<2.68$ \\
\hline Barium, total, $\mu \mathrm{g} / \mathrm{L}$ & 4.93 & 4.88 & 4.91 & 4.82 \\
\hline Beryllium, total, $\mu \mathrm{g} / \mathrm{L}$ & $<0.15$ & $<0.15$ & $<0.15$ & $<0.15$ \\
\hline Calcium, total, mg/L & 47.0 & 47.9 & 47.9 & 47.0 \\
\hline Chromium, total, $\mu \mathrm{g} / \mathrm{L}$ & 2.43 & 2.21 & 2.31 & 2.05 \\
\hline Cobalt, total, $\mu \mathrm{g} / \mathrm{L}$ & $<0.31$ & $<0.31$ & $<0.31$ & $<0.31$ \\
\hline Copper, total, $\mu \mathrm{g} / \mathrm{L}$ & $<0.36$ & $<0.36$ & 2.05 & 3.56 \\
\hline Iron, total, $\mu \mathrm{g} / \mathrm{L}$ & 11.5 & 9.21 & 21.4 & 5.90 \\
\hline Magnesium, total, mg/L & 14.2 & 13.8 & 13.2 & 14.4 \\
\hline Manganese, total, $\mu \mathrm{g} / \mathrm{L}$ & $<1.88$ & $<1.88$ & $<1.88$ & $<1.88$ \\
\hline Molybdenum, total, $\mu \mathrm{g} / \mathrm{L}$ & $<1.17$ & $<1.17$ & $<1.17$ & $<1.17$ \\
\hline Nickel, total, $\mu \mathrm{g} / \mathrm{L}$ & $<1.17$ & $<1.17$ & $<1.17$ & $<1.17$ \\
\hline Strontium, total, $\mu \mathrm{g} / \mathrm{L}$ & 84.1 & 82.5 & 81.7 & 81.9 \\
\hline Vanadium, total, $\mu \mathrm{g} / \mathrm{L}$ & 1.85 & 1.57 & 1.69 & 1.56 \\
\hline Zinc, total, $\mu \mathrm{g} / \mathrm{L}$ & 5.81 & 116 & 148 & 172 \\
\hline Nitrogen, nitrate by difference, $\mathrm{mg} / \mathrm{L}$ as $\mathrm{N}$ & ND & 0.230 & 0.240 & 0.210 \\
\hline Nitrogen, nitrite, $\mathrm{mg} / \mathrm{L}$ as $\mathrm{N}$ & ND & $<0.001$ & $<0.001$ & $<0.001$ \\
\hline Nitrogen, nitrite plus nitrate, $\mathrm{mg} / \mathrm{L}$ as $\mathrm{N}$ & ND & 0.230 & 0.240 & 0.210 \\
\hline Odor, threshold, TON & ND & NOD & NOD & NOD \\
\hline Potassium, total, mg/L & 0.50 & 0.39 & 0.42 & 0.34 \\
\hline Selenium, total, $\mu \mathrm{g} / \mathrm{L}$ & $<0.84$ & $<0.84$ & $<0.84$ & $<0.84$ \\
\hline Silica, dissolved, mg/L & ND & 15.86 & 16 & 15.97 \\
\hline Sodium, total, mg/L & 2.52 & 2.48 & 2.51 & 2.45 \\
\hline Sulfate, total, mg/L & ND & 1.8 & 1.8 & 1.9 \\
\hline Residue, total filterable@180 ${ }^{\circ} \mathrm{C}, \mathrm{mg} / \mathrm{L}$ & ND & 202 & 198 & 197 \\
\hline Hardness, $\mathrm{mg} / \mathrm{L}$ as $\mathrm{Ca}$ & ND & 181 & 177 & 183 \\
\hline Carbon, total organic, mg/L & ND & 0.4 & 0.4 & 0.4 \\
\hline Turbidity, NTU & ND & 0.19 & 0.18 & 0.10 \\
\hline
\end{tabular}




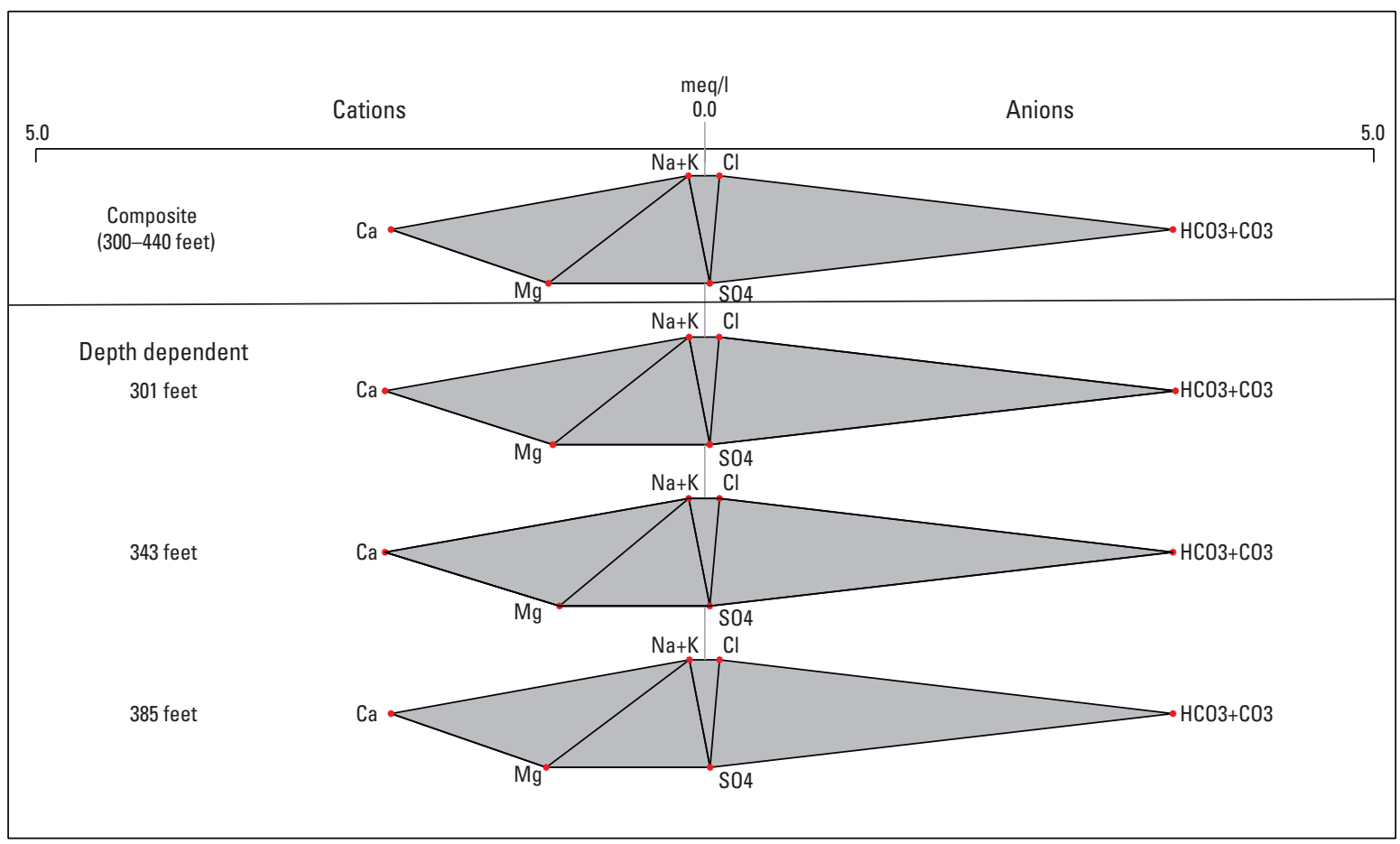

Figure 2. Stiff diagrams comparing the major ion concentrations of four water samples collected at the City of Tallahassee test well 32, December 2013.

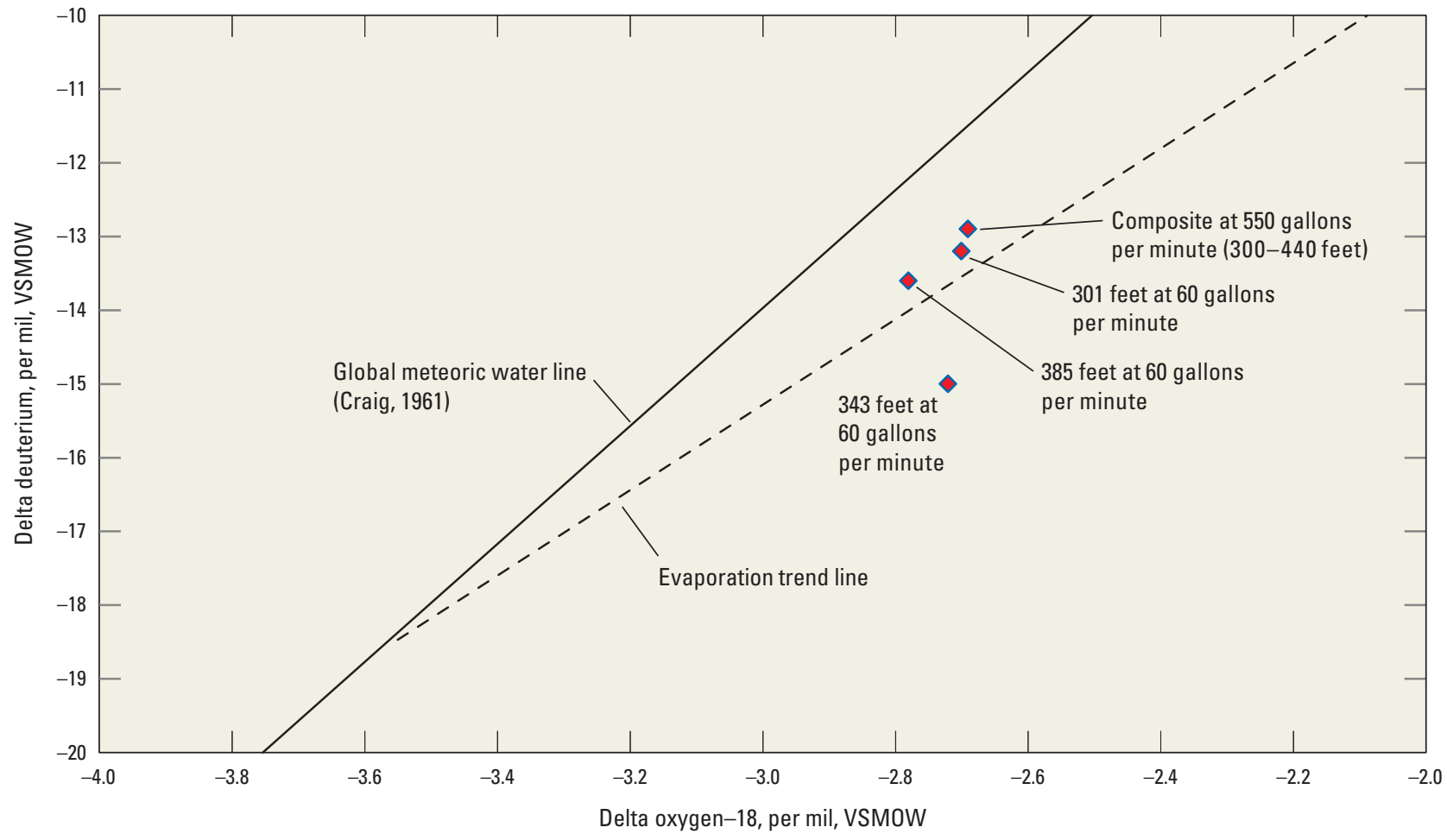

Figure 3. Content of delta deuterium and delta oxygen-18 in water samples collected from the City of Tallahassee test well 32 relative to the global meteoric water line in December 2013. 
Table 2. Volatile organic compounds in groundwater samples collected from City of Tallahasse test well 32 (U.S. Geological Survey site 303408084152300 COT $440 \mathrm{ft}$ UFA Test Well at Tallahassee, FL), December 2013.

[EST, Eastern Standard Time]

\begin{tabular}{|c|c|c|c|c|}
\hline \multirow{2}{*}{$\begin{array}{c}\text { Sample } \\
\text { description }\end{array}$} & \multicolumn{4}{|c|}{$\begin{array}{l}\text { Concentration of organic compounds, } \\
\text { in micrograms per liter }\end{array}$} \\
\hline & $\begin{array}{l}\text { Composite sample } \\
\text { from } 300 \text { to } 440 \text { feet }\end{array}$ & $\begin{array}{l}\text { Depth-dependent } \\
\text { sample at } 301 \text { feet }\end{array}$ & $\begin{array}{l}\text { Depth-dependent } \\
\text { sample at } 343 \text { feet }\end{array}$ & $\begin{array}{l}\text { Depth-dependent } \\
\text { sample at } 385 \text { feet }\end{array}$ \\
\hline Date & $12 / 3 / 2013$ & $12 / 4 / 2013$ & $12 / 4 / 2013$ & $12 / 4 / 2013$ \\
\hline Time (EST) & 1600 & 1500 & 1400 & 1200 \\
\hline 1,1,1,2-Tetrachloroethane & $<0.030$ & $<0.030$ & $<0.030$ & $<0.030$ \\
\hline 1,1,1-Trichloroethane & $<0.030$ & $<0.030$ & $<0.030$ & $<0.030$ \\
\hline 1,1,2,2-Tetrachloroethane & $<0.040$ & $<0.040$ & $<0.040$ & $<0.040$ \\
\hline 1,1,2-Trichloroethane & $<0.030$ & $<0.030$ & $<0.030$ & $<0.030$ \\
\hline 1,1-Dichloroethane & $<0.030$ & $<0.030$ & $<0.030$ & $<0.030$ \\
\hline 1,1-Dichloroethylene & $<0.040$ & $<0.040$ & $<0.040$ & $<0.040$ \\
\hline 1,1-Dichloropropene & $<0.030$ & $<0.030$ & $<0.030$ & $<0.030$ \\
\hline 1,2,3-Trichlorobenzene & $<0.060$ & $<0.060$ & $<0.060$ & $<0.060$ \\
\hline 1,2,3-Trichloropropane & $<0.150$ & $<0.150$ & $<0.150$ & $<0.150$ \\
\hline 1,2,4-Trichlorobenzene & $<0.040$ & $<0.040$ & $<0.040$ & $<0.040$ \\
\hline 1,2,4-Trimethylbenzene & $<0.030$ & $<0.030$ & $<0.030$ & $<0.030$ \\
\hline 1,2-Dibromo-3-chloropropane & $<0.020$ & $<0.020$ & $<0.020$ & $<0.020$ \\
\hline 1,2-Dibromoethane & $<0.070$ & $<0.070$ & $<0.070$ & $<0.070$ \\
\hline 1,2-Dichlorobenzene & $<0.030$ & $<0.030$ & $<0.030$ & $<0.030$ \\
\hline 1,2-Dichloroethane & $<0.030$ & $<0.030$ & $<0.030$ & $<0.030$ \\
\hline 1,2-Dichloropropane & $<0.030$ & $<0.030$ & $<0.030$ & $<0.030$ \\
\hline 1,3,5-Trimethylbenzene & $<0.030$ & $<0.030$ & $<0.030$ & $<0.030$ \\
\hline 1,3-Dichlorobenzene & $<0.040$ & $<0.040$ & $<0.040$ & $<0.040$ \\
\hline 1,3-Dichloropropane & $<0.030$ & $<0.030$ & $<0.030$ & $<0.030$ \\
\hline 1,4-Dichlorobenzene & $<0.040$ & $<0.040$ & $<0.040$ & $<0.040$ \\
\hline 2,2-Dichloropropane & $<0.040$ & $<0.040$ & $<0.040$ & $<0.040$ \\
\hline 2-Chlorotoluene & $<0.020$ & $<0.020$ & $<0.020$ & $<0.020$ \\
\hline 4-Chlorotoluene & $<0.030$ & $<0.030$ & $<0.030$ & $<0.030$ \\
\hline Benzene & $<0.040$ & $<0.040$ & $<0.040$ & $<0.040$ \\
\hline Bromobenzene & $<0.030$ & $<0.030$ & $<0.030$ & $<0.030$ \\
\hline Bromochloromethane & $<0.040$ & $<0.040$ & $<0.040$ & $<0.040$ \\
\hline Bromodichloromethane & $<0.040$ & $<0.040$ & $<0.040$ & $<0.040$ \\
\hline Bromoform & $<0.080$ & $<0.080$ & $<0.080$ & $<0.080$ \\
\hline Bromomethane & $<0.100$ & $<0.100$ & $<0.100$ & $<0.100$ \\
\hline Carbon tetrachloride & $<0.030$ & $<0.030$ & $<0.030$ & $<0.030$ \\
\hline Chlorobenzene & $<0.030$ & $<0.030$ & $<0.030$ & $<0.030$ \\
\hline Chloroethane & $<0.050$ & $<0.050$ & $<0.050$ & $<0.050$ \\
\hline Chloroform & $<0.100$ & $<0.100$ & $<0.100$ & $<0.100$ \\
\hline Chloromethane & $<0.080$ & $<0.080$ & $<0.080$ & $<0.080$ \\
\hline cis-1,2-Dichloroethylene & $<0.030$ & $<0.030$ & $<0.030$ & $<0.030$ \\
\hline cis-1,3-Dichloropropylene & $<0.030$ & $<0.030$ & $<0.030$ & $<0.030$ \\
\hline Dibromochloromethane & $<0.040$ & $<0.040$ & $<0.040$ & $<0.040$ \\
\hline
\end{tabular}


Table 2. Volatile organic compounds in groundwater samples collected from City of Tallahasse test well 32 (U.S. Geological Survey site 303408084152300 COT 440 ft UFA Test Well at Tallahassee, FL), December 2013. - Continued

[EST, Eastern Standard Time]

\begin{tabular}{|c|c|c|c|c|}
\hline \multirow{2}{*}{$\begin{array}{c}\text { Sample } \\
\text { description }\end{array}$} & \multicolumn{4}{|c|}{$\begin{array}{l}\text { Concentration of organic compounds, } \\
\text { in micrograms per liter }\end{array}$} \\
\hline & $\begin{array}{l}\text { Composite sample } \\
\text { from } 300 \text { to } 440 \text { feet }\end{array}$ & $\begin{array}{l}\text { Depth-dependent } \\
\text { sample at } 301 \text { feet }\end{array}$ & $\begin{array}{l}\text { Depth-dependent } \\
\text { sample at } 343 \text { feet }\end{array}$ & $\begin{array}{l}\text { Depth-dependent } \\
\text { sample at } 385 \text { feet }\end{array}$ \\
\hline Dibromomethane & $<0.030$ & $<0.030$ & $<0.030$ & $<0.030$ \\
\hline Dichlorodifluoromethane & $<0.030$ & $<0.030$ & $<0.030$ & $<0.030$ \\
\hline Ethylbenzene & $<0.030$ & $<0.030$ & $<0.030$ & $<0.030$ \\
\hline Hexachlorobutadiene & $<0.040$ & $<0.040$ & $<0.040$ & $<0.040$ \\
\hline Isopropylbenzene & $<0.020$ & $<0.020$ & $<0.020$ & $<0.020$ \\
\hline Methylenechloride & $<0.030$ & $<0.030$ & $<0.030$ & $<0.030$ \\
\hline MTBE & $<0.050$ & $<0.050$ & $<0.050$ & $<0.050$ \\
\hline Naphthalene & $<0.040$ & $<0.040$ & $<0.040$ & $<0.040$ \\
\hline n-Butylbenzene & $<0.020$ & $<0.020$ & $<0.020$ & $<0.020$ \\
\hline n-Propylbenzene & $<0.030$ & $<0.030$ & $<0.030$ & $<0.030$ \\
\hline p-Isopropyltoluene & $<0.030$ & $<0.030$ & $<0.030$ & $<0.030$ \\
\hline sec-Butylbenzene & $<0.020$ & $<0.020$ & $<0.020$ & $<0.020$ \\
\hline Styrene & $<0.040$ & $<0.040$ & $<0.040$ & $<0.040$ \\
\hline t-Butylbenzene & $<0.030$ & $<0.030$ & $<0.030$ & $<0.030$ \\
\hline Tetrachloroethylene & $<0.040$ & $<0.040$ & $<0.040$ & $<0.040$ \\
\hline Toluene & $<0.030$ & 0.490 & 1.240 & 1.740 \\
\hline Total Xylenes & $<0.050$ & $<0.050$ & $<0.050$ & $<0.050$ \\
\hline trans-1,2-Dichloroethylene & $<0.030$ & $<0.030$ & $<0.030$ & $<0.030$ \\
\hline trans-1,3-Dichloropropylene & $<0.040$ & $<0.040$ & $<0.040$ & $<0.040$ \\
\hline Trichloroethylene & $<0.030$ & $<0.030$ & $<0.030$ & $<0.030$ \\
\hline Trichlorofluoromethane & $<0.030$ & $<0.030$ & $<0.030$ & $<0.030$ \\
\hline Vinyl chloride & $<0.030$ & $<0.030$ & $<0.030$ & $<0.030$ \\
\hline
\end{tabular}




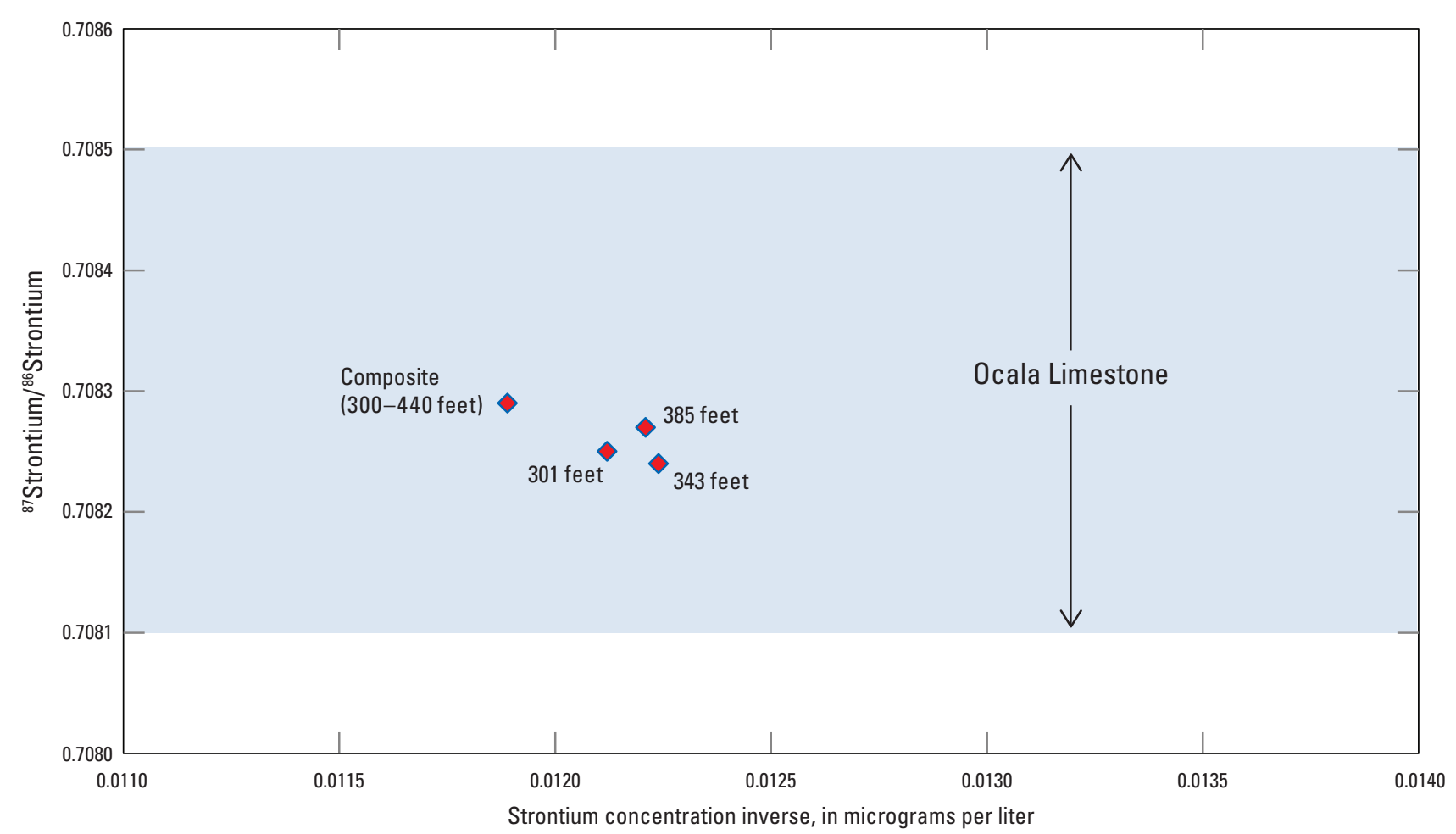

Figure 4. Relation between strontium isotope ratios and the inverse of the strontium concentration in water samples collected at the City of Tallahassee test well 32, December 2013.

\section{Age Dating}

$\mathrm{SF}_{6}$ data indicate that water produced by the CW32 open interval recharged to the groundwater system from 26.2 to 29.4 years ago. The composite sample collected at $550 \mathrm{gal} / \mathrm{min}$ yielded the youngest date -26.2 years. The depth-dependent samples ranged in age from 27.4 to 29.4 years; the samples from the greatest depth had the greatest ages (table 3 ). The piston-flow model used to relate $\mathrm{SF}_{6}$ concentration to age assumes that a parcel of water moves through a flow system with no mixing, but that is an unlikely scenario in a karst system. Therefore, the modeled ages most likely represent an average age for the mixture of waters produced by the well. The composite sample likely contains a relatively larger fraction of slightly younger water than from the discrete zones because the higher pump rate used during sample collection may have pulled younger water down from the overlying low permeability Hawthorn Group. This conclusion is supported by the ${ }^{87} \mathrm{Sr} /{ }^{86} \mathrm{Sr}$ data because the isotopic ratio of the composite sample was slightly higher than that of the discrete samples (fig. 4). The Hawthorn Group is known to have higher ${ }^{87} \mathrm{Sr} /{ }^{86} \mathrm{Sr}$ ratios than the Ocala Formation (Brewster-Wingard and others, 1997).

Tritium data corroborate the groundwater ages determined by $\mathrm{SF}_{6}$ dating and verify that most of the water produced by CW32 recharged to the groundwater system after hydrogen-bomb testing began in 1952. Tritium concentrations in the samples varied from 1.15 to 1.4 tritium units (TU; table 3). When the CW32 data are corrected for radioactive decay, using the range of recharge ages calculated from $\mathrm{SF}_{6}$ data, the concentration of ${ }^{3} \mathrm{H}$ ranged from 5.0 to $7.0 \mathrm{TU}$ at the time of recharge. The average ${ }^{3} \mathrm{H}$ concentration in rainfall at Ocala, Fla., was 9.9 TU in 1984 and decreased to 4.7 TU by 1988 (International Atomic Energy Agency, 2014); therefore, ${ }^{3} \mathrm{H}$ data measured in this study support the calculated dates for $\mathrm{SF}_{6}$ recharge. Water recharged prior to 1952 would contain ${ }^{3} \mathrm{H}$ at levels well below the $0.3 \mathrm{TU}$ reporting limit of the analysis because the half-life of ${ }^{3} \mathrm{H}$ is 12.43 years. CW32 likely produces little or no water recharged prior to 1952. 
Table 3. Field measurements, tracer, and age data collected from City of Tallahassee test well 32, (U.S. Geological Survey site 303408084152300 COT $440 \mathrm{ft}$ UFA Test Well at Tallahassee, FL), December 2013.

[EST, Eastern Standard Time; ft blw LSD, feet below land surface datum; gal $/ \mathrm{min}$, gallons per minute; min, minutes; ${ }^{\circ} \mathrm{C}$, degrees Celsius; $\mu \mathrm{S} / \mathrm{cm}$, microsiemens per centimeter at 25 degrees Celsius; $\mathrm{mg} / \mathrm{L}$, milligrams per liter; NTRU, nephelometric turbidity ratio units; CaCO3, calcium carbonate; avg, average; $\mathrm{fg} / \mathrm{kg}$, femtograms per kilogram; std, standard; $\delta^{18} \mathrm{O}$, oxygen-18 to oxygen-16 ratio; $\delta^{2} \mathrm{H}$, hydrogen-2 to hydrogen ratio, reported relative to Vienna Standard Mean Ocean Water (VSMOW); ${ }^{3} \mathrm{H}$, tritium; TU, tritium units; ${ }^{87} \mathrm{Sr} /{ }^{86} \mathrm{Sr}$, strontium-87 to strontium- 86 ratio]

\begin{tabular}{|c|c|c|c|c|}
\hline Sample description & $\begin{array}{l}\text { Composite sample } \\
\text { from } 300 \text { to } 440 \text { feet }\end{array}$ & $\begin{array}{l}\text { Depth-dependent } \\
\text { sample at } 301 \text { feet }\end{array}$ & $\begin{array}{l}\text { Depth-dependent } \\
\text { sample at } 343 \text { feet }\end{array}$ & $\begin{array}{l}\text { Depth-dependent } \\
\text { sample at } 385 \text { feet }\end{array}$ \\
\hline Date & $12 / 3 / 2013$ & $12 / 4 / 2013$ & $12 / 4 / 2013$ & $12 / 4 / 2013$ \\
\hline Sample start time (EST) & 1600 & 1500 & 1400 & 1200 \\
\hline Water level, ft blw LSD & 194 & 194 & 194 & 194 \\
\hline Flow rate, gal $/ \mathrm{min}$ & 550 & 60 & 60 & 60 \\
\hline Pumping period, min & 55 & 24 & 28 & 60 \\
\hline Sampling depth, ft blw LSD & 300 & 301 & 343 & 385 \\
\hline Water temperature, ${ }^{\circ} \mathrm{C}$ & 20.9 & 20.9 & 21.4 & 21.3 \\
\hline Specific conductance (field), $\mu \mathrm{S} / \mathrm{cm}$ & 330 & 340 & 339 & 344 \\
\hline $\mathrm{pH}$ (field) & 7.4 & 7.4 & 7.4 & 7.5 \\
\hline Dissolved oxygen (field), mg/L & 3.9 & 3.4 & 0.3 & 2.8 \\
\hline Turbidity (field), NTRU & 1 & 0.4 & 0.3 & 0.3 \\
\hline Alkalinity (field), $\mathrm{mg} / \mathrm{L}$ as $\mathrm{CaCO}_{3}$ & 176 & 185 & 183 & 184 \\
\hline Bicarbonate (field), mg/L & 214 & 225 & 222 & 224 \\
\hline Carbonate (field), $\mathrm{mg} / \mathrm{L}$ & 0.4 & 0.3 & 0.3 & 0.3 \\
\hline Sulfur hexafluoride $\left(\mathrm{SF}_{6}\right)(\mathrm{avg}), \mathrm{fg} / \mathrm{kg}$ & 191.5 & 152.5 & 146 & 117.5 \\
\hline $\begin{array}{l}\text { Sulfur hexafluoride }\left(\mathrm{SF}_{6}\right) \text { piston flow } \\
\text { model age (avg), years }\end{array}$ & 26.2 & 27.4 & 27.7 & 29.4 \\
\hline $\begin{array}{l}\text { Sulfur hexafluoride }\left(\mathrm{SF}_{6}\right) \text { piston flow } \\
\text { model recharge year (avg) }\end{array}$ & 1988 & 1986.5 & 1986 & 1984.5 \\
\hline$\delta^{18} \mathrm{O}, \mathrm{VSMOW}$ & -2.69 & -2.7 & -2.72 & -2.78 \\
\hline$\delta^{2} \mathrm{H}, \mathrm{VSMOW}$ & -12.9 & -13.2 & -15 & -13.6 \\
\hline${ }^{3} \mathrm{H}, \mathrm{TU}$ & 1.15 & 1.40 & 1.27 & 1.34 \\
\hline${ }^{87} \mathrm{Sr} /{ }^{86} \mathrm{Sr}$ & 0.708 & 0.708 & 0.708 & 0.708 \\
\hline
\end{tabular}

\section{Summary and Conclusions}

The U.S. Geological Survey, in cooperation with the City of Tallahassee, completed a study to delineate highpermeability zones in the Upper Florida aquifer that have substantial rates of groundwater flow and to characterize changes in water quality with depth in the borehole of test well CW32 (CW32). Borehole-geophysical data were used to delineate high-permeability zones in the open interval of CW32. Water-chemistry data were used to determine the quality of water in the test well. Naturally occurring tracers were used to determine whether the high-flow zones in CW32 produce water from similar sources, whereas age-dating was used to determine the approximate date of recharge (approximately 26 to 29 years ago) and if water from each of the highly permeable zones in CW32 is of similar age.

The open interval in CW32 produces water of similar (consistently) high quality throughout its length. Results of water-quality, tracer, and age-dating analyses indicate that the quality, source, flow path, and age of the water produced by CW32 are comparable in each of the three highly permeable zones identified using geophysical techniques. The cavernous nature of much of the open interval is an indication that the three productive zones are likely interconnected in the aquifer system by secondary porosity features. Changes to the CW32 open interval, as constructed during testing, would likely provide little or no improvement in the high-quality water produced by the well. 


\section{References Cited}

Brewster-Wingard, G.L., Scott, T.M., Edwards, L.E., Weedman, S.D., and Simmons, K.R., 1997, Reinterpretation of the peninsular Florida Oligocene: an integrated approach: Sedimentary Geology, v. 108, p. 207-228.

Busenberg, E., and Plummer, L.N., 2000, Dating young groundwater with sulfur hexafluoride-Natural and anthropogenic sources of sulfur hexafluoride: Water Resources Research, v. 35, no. 10, p. 3011-3030.

Collar, R.J., and Mock, P.A., 1997, Using water-supply wells to investigate vertical groundwater quality: Ground Water, v. 35 , no. 5 , p. $743-750$.

Coplen, T.B., Wildman, J.D., and Landwehr, J.M., 1991, Improvements in the gaseous hydrogen-water equilibrium technique for hydrogen isotope-ratio analysis: Analytical Chemistry, v. 63, p. 910-912.

Craig, Harmon, 1961, Isotopic variations in meteoric waters: Science, v. 133, no. 3465, p. 1702-1703.

Dansgaard, W., 1964, Stable isotopes in precipitation: Tellus, v. 16 , no. 4 , p. $436-468$.

Danskin, W.R., and Church, C.D., 2005, Determining age and vertical contribution of ground water pumped from wells in a small coastal river basin: U.S. Geological Survey Open-File Report 2005-1032, 4 p.

Davis, J.H., and Katz, B.G., 2007, Hydrogeologic investigation, water chemistry analysis, and model delineation of contributing areas for City of Tallahassee public supply wells, Tallahassee, Florida: U.S. Geological Survey Scientific Investigations Report 2007-5070, 67 p.

Gossell, M.A., Nishikawa, T., Hansen, R.T., Izbicki, J.A., Tabidian, M.A., and Bertine, K., 1999, Application of flowmeter and depth-dependent water quality data for improved production well construction: Ground Water, v. 37, no. 5, p. 729-735.

Ingraham, N.L., 1998 [2006 ed.], Isotopic variations in precipitation, chap. 3 of Kendall, C., and McDonnell, J.J., eds., Environmental tracers in catchment hydrology: Amsterdam, Elsevier, p. 87-118.

International Atomic Energy Agency, 2014, Water isotope system for data analysis, visualization, and electronic retrieval (WISER), accessed September 5, 2014, at $h t t p: / /$ www-naweb.iaea.org/napc/ih/IHS_resources_isohis.html.

Izbicki, J.A., Christensen, A.H., and Hanson, R.T., 1999, U.S. Geological Survey combined well-bore flow and depthdependent water sampler: U.S. Geological Survey Fact Sheet 196-99, 2 p.

Izbicki, J.A., Christensen, A.H., Newhouse, M.W., and Aiken, G.R., 2005, Inorganic, isotopic, and organic composition of high-chloride water from wells in a coastal southern California aquifer: Applied Geochemistry, v. 20, no. 14 , p. 96-1517.
Izbicki, J.A., Stamos, C.L., Metzger, L.F., Halford, K.J., Kulp, T.R., and Bennett, G.L., 2008, Source, distribution, and management of arsenic in water from wells, Eastern San Joaquin ground-water subbasin, California: U.S. Geological Survey Open-File Report 2008-1272, 8 p.

Katz, B.G., and Bullen, T.D., 1996, The combined use of ${ }^{87} \mathrm{Sr} /{ }^{86} \mathrm{Sr}$ and carbon and water isotopes to study the hydrochemical interaction between groundwater and lakewater in mantled karst: Geochimica et Cosmichimica Acta, v. 60, no. 24 , p. 5075-5087.

Katz, B.G., Coplen, T.B., Bullen, T.D., and Davis, J.H., 1997, Use of chemical and isotopic tracers to characterize the interactions between ground water and surface water in mantled karst: Ground Water, v. 35, no. 6, p. 1014-1028.

Keys, W.S., 1990, Borehole geophysics applied to groundwater investigations: U.S. Geological Survey Techniques of Water-Resources Investigations, book 2, chap. E2, 150 p.

Landon, M.K., Jurgens, B.C., Katz, B.G., Eberts, S.M., Burow, K.R., and Crandall, C.A., 2009, Depth-dependent sampling to identify short-circuit pathways to public-supply wells in multiple aquifer settings in the United States: Hydrogeology Journal, v. 18, no. 3, p. 577-593.

Miller, J.A., 1986, Hydrologic framework of the Floridan aquifer system in Florida and parts of Georgia, Alabama, and South Carolina: U.S. Geological Survey Professional Paper 1403-B, 91 p.

Prensky, S.E., 1999, Advances in borehole imaging technology and applications, in Lovell, M.A., Williamson, G., and Harvey, P.K., eds., Borehole imaging-Applications and case histories: London, Geological Society, Special Publications 159, p. 1-43.

U.S. Environmental Protection Agency, 2014, Drinking water contaminants, accessed September 5, 2014, at http://water. epa.gov/drink/contaminants/index.cfm.

U.S. Geological Survey, variously dated, National field manual for the collection of water-quality data: U.S. Geological Survey Techniques of Water Resources Investigations, book 9, chaps. A1-A9, available online at http://pubs.water. usgs.gov/twri9A.

Wacker, M.A., Cunningham, K.J., and Williams, J.H., 2014, Geologic and hydrogeologic frameworks of the Biscayne aquifer in central Miami-Dade County, Florida: U.S. Geological Survey Scientific Investigations Report 2014-5138, 66 p., accessed November 20, 2014, at http://dx.doi.org/10.3133/sir20145138.

Williams, J.H., and Johnson, C.D., 2004, Acoustic and optical borehole wall imaging for fractured-rock aquifer studies: Journal of Applied Geophysics, v. 55, p. 151-159. 
Appendix 1. Comparison of borehole image, geophysical, water quality, flowmeter, and sonic logs showing evidence of three productive intervals in the City of Tallahassee test well 32 at Leon County, Florida, December 2013. Only the data collected in the open interval of the test well are displayed at 1 to 96 scale.

File can be downloaded from http://pubs.usgs.gov/of/2014/1255/.

Appendix 2. Comparison of borehole image, geophysical, water quality, flowmeter, and sonic logs showing evidence of three productive intervals in the City of Tallahassee test well 32 at Leon County, Florida, December 2013. The full geophysical log is displayed at 1 to 12 scale. 
Manuscript approved December 18, 2014

Prepared by the USGS Science Publishing Network Raleigh Publishing Service Center

Edited by Kay P. Naugle

Illustrations by Kimberly A. Swidarski

Layout by Caryl J. Wipperfurth

For more information concerning this report, contact:

Director

U.S. Geological Survey

Caribbean-Florida Water Science Center

4446 Pet Lane, Suite 108

Lutz, FL 33559

(813) 498-5000

or visit our Web site at: http://fl.water.usgs.gov 
